\title{
La supuesta basílica de San Vicente en Córdoba: de mito histórico a obstinación historiográfica
}

\section{The Alleged Basilica of Saint Vincent of Córdoba: From a Historical Myth to an Obstinacy of Historiography}

\author{
Fernando Arce-Sainz \\ CCHS-CSIC, Madrid, España
}

Bajo el suelo de la mezquita aljama de Córdoba hay restos materiales en torno a los cuales se han desarrollado discursos históricos cuyo punto de partida es admitir que, en ese solar, se levantaron con anterioridad establecimientos religiosos cristianos que fueron demolidos para dejar espacio al oratorio musulmán impulsado por los omeyas. Primero fue la legendaria y literaria iglesia de San Vicente, que ante el asombro de muchos no se materializó tras las excavaciones de los años 30. Décadas después, arrinconado el mito pero nunca olvidado, el paisaje urbano previo a la mezquita se ha convertido en un complejo episcopal. Modelos historiográficos en boga están permitiendo nuevas interpretaciones de unos materiales arqueológicos que, en su momento, llevaron a los excavadores a rechazar la presencia segura de iglesias. En el presente trabajo se defiende lo que otros han expresado con anterioridad: que, en virtud del conocimiento arqueológico existente, no hay argumentos de peso que aboguen por la presencia de edificios cristianos previos. No es por tanto nuestro estudio ninguna novedad en su apartado conclusivo. Sí es original en su planteamiento y desarrollo ya que se pretende hacer una contextualización historiográfica de las interpretaciones de unos datos históricos (textuales y arqueológicos) una y otra vez revisados.

Palabras clave: mito histórico; obstinación historiográfica; memoria literaria; registro material.
Underneath the Great-Mosque of Cordoba, there are some archaeological remains which have been the origin of several historiographical debates. The core of these debates was the idea that there were previous Christian buildings in the site later demolished to make room for the Umayyad mosque. However, the documented church of Saint Vincent, for the astonishment of many, did not appear in the excavations made in the 1930s. Much later, set aside the myth, but never truly forgotten, the idea that there might have been a full episcopal complex suceeded the other. Recent historigraphical developments are building new interpretations upon an archaeological evidence, that drove archaeologists, in the past, to deny definitively the presence of these ecclesiastical premises. This article argues what others have already stated: that according to the present archaeological knowledge, no evidence shows that there were previous Christian buildings under the Umayyad mosque. In terms of our conclusions, the article is not original. The main aim of this contribution is to offer a new and neccesary contextualizacion of textual and archaeological interpretations of emphirical data.

Key words: Historic myth; Historiographical stubborness; Historical myth; Material records. 


\section{Introducción}

Entre 1930 y 1936 se hicieron exploraciones arqueológicas en la Mezquita de Córdoba bajo la dirección del arquitecto don Félix Hernández Giménez (figura 1). Una de las razones que animaron esos trabajos fue sacar a la luz los restos de una iglesia que se creía amortizada como consecuencia de la construcción de la primera mezquita aljama en tiempos de 'Abd al-Raḥmān I. Las pruebas de su existencia se basaban en testimonios literarios a partir de los cuales nada se podía aventurar respecto a su realidad material. A pesar de todo se había construido una imagen del edificio desaparecido, aunque en una clave eminentemente simbólica.

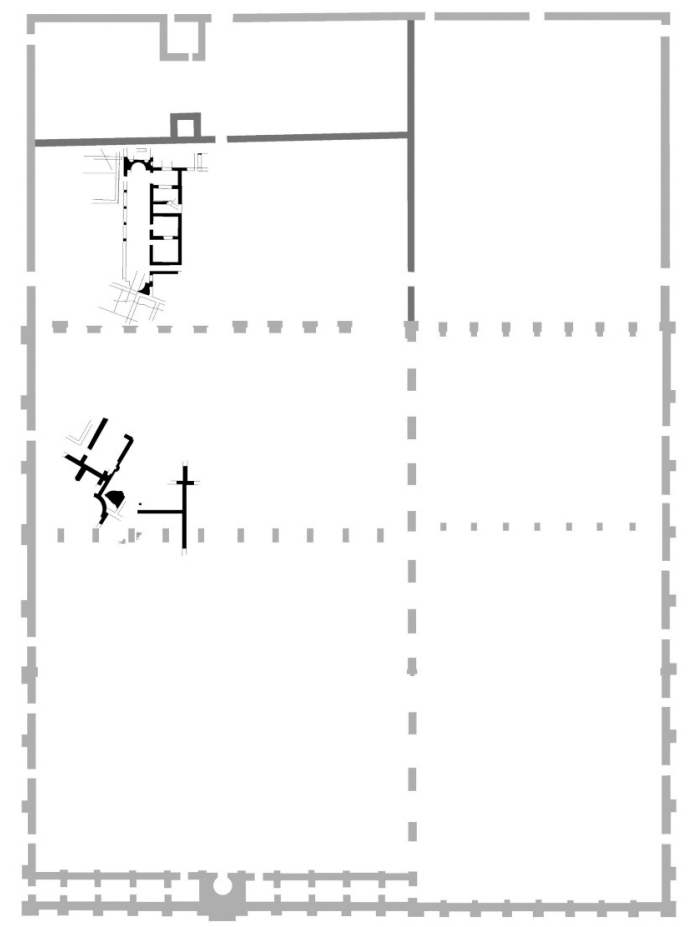

Figura 1. Localización de las estructuras encontradas por Félix Hernández. Plano realizado a partir de la información de Félix Hernández revisada por Pedro Marfil y Antonio Fernández-Puertas, publicado en José Manuel Bermúdez, "El atrium del complejo episcopal cordubensis. Una propuesta sobre la funcionalidad de las estructuras tardoantiguas del patio de la mezquita de Córdoba", Romula, 9 (2010), pp. 315-341. 
El hecho de que bajo un edificio islámico de gran relevancia (la mezquita aljama de los omeyas, conquistadores y forjadores de al-Andalus) estuviera sepultado un templo cristiano se convertía en poderosa imagen de la descomposición de un mundo y los albores de otro. La gran mezquita representa el triunfo y engrandecimiento de un poder y una cultura que dejaron en el edificio las huellas de su éxito. Pero sus cimientos penetran cual raíces en el pasado inmediato del que se nutrió, como insistía una historiografía conservadora que consideraba que la España musulmana de los primeros siglos era fuertemente tradicional respecto al legado hispano tardoantiguo. En el plano artístico, el peso de la tradición creativa preislámica en la nueva plástica musulmana encontraba argumentos en la propia mezquita. En sus fases emirales la presencia de un abundante elenco de materiales reutilizados se toma como argumento en este sentido. Existían propuestas que, incluso, defendían que partes de la primera mezquita eran directamente alzados conservados de la iglesia previa. Esta iglesia sería el templo catedralicio de la Córdoba tardoantigua. Antes de su destrucción, además, fue compartido su uso con los musulmanes.

No sabemos hasta qué punto estas cuestiones le rondaban en la cabeza a Hernández cuando empezó a excavar. Sí es seguro que las expectativas eran bastante grandes. Sin embargo, concluidos los trabajos, cundió el desánimo ante la imposibilidad de dar corporeidad al escenario artístico imaginado. Entre los diferentes restos materiales exhumados no había para Hernández nada que pudiera identificarse con un destacado edificio de culto cristiano. Como consecuencia de la decepción parece que Hernández renunció a comunicar de forma pública los resultados, demasiado desmitificadores. No se puede decir ni mucho menos que ocultara la información: «[...], muchos datos sobre la Mezquita descubiertos y divulgados verbalmente por don Félix Hernández los han dado a conocer diversos autores en sus escritos, a veces sin citar la fuente originaria, $[\ldots]^{1} \gg$.

El mito empezó a tambalearse pero no terminó arrumbado. Aunque había perdido su capa externa de monumentalidad, otros componentes simbólicos no se sentían cuestionados por los resultados de las exca-

\footnotetext{
1 Vicent, "Perfil científico y humano de D. Félix Hernández", p. 179.
} 
vaciones. Manuel Ocaña ${ }^{2}$ se enfrentó a los adversos datos arqueológicos y trató de ajustarlos a una revisión crítica de las distintas noticias literarias que aluden a la presencia en la zona de una iglesia. Busca una explicación en la que todos los datos puedan ser integrados, a pesar de sus contradicciones. Tras varias enmiendas al relato tradicional llega a la conclusión de que no hubo un monumental edificio objeto de partición sino la total expropiación de una iglesia discreta en su dimensión artística. No obstante, está convencido de que los cristianos contaron con un espacio propio e independiente del anterior en el que siguieron practicando su liturgia hasta el momento de levantarse la mezquita aljama. Este nuevo escenario, ahora con dos iglesias, es muy distinto al solitario templo que primero fue compartido y luego totalmente expropiado. Propone Ocaña, tiempo después ${ }^{3}$, que en esta parte de la ciudad había un cenobio dedicado a San Vicente cuya iglesia los musulmanes toman para sí, aunque permitiendo que el culto cristiano continuara en algún otro lugar perteneciente al complejo monástico. Dicho esto, el resto del discurso sigue más o menos inalterado. Continuamos teniendo un paisaje urbano cristianizado que será desbaratado cuando se levante el principal oratorio musulmán de la ciudad. En cuanto al asunto de la forzada bipolaridad cultual nada impide en apariencia ponerla en duda más allá de un cambio en lo relativo al escenario: dos espacios aledaños independientes en vez de uno solo dividido.

En los últimos años el mito de San Vicente está recobrando el brillo monumental perdido tras las excavaciones y la cura de humildad artística de la relectura de Ocaña. Revisiones de la escasa información que dejó Hernández, junto a nuevas exploraciones arqueológicas y un nuevo contexto historiográfico relativo al conocimiento del mundo tardoantiguo, están dando lugar a interpretaciones que reivindican un destacado perfil monumental cristiano previo a la construcción de la mezquita. San Vicente ya no es visto como una basílica aislada ni como un monasterio sino como parte del complejo edilicio episcopal cordobés de época visigoda.

\footnotetext{
${ }^{2}$ Ocaña, "La basílica de San Vicente y la gran mezquita de Córdoba. Nuevo examen de los textos".

3 Ocaña, "El mito de la Basílica de San Vicente de Córdoba".
} 


\section{Noticias referidas a iglesias (y mezquitas) en las fuentes escritas}

El expediente literario está formado por textos siempre árabes ${ }^{4}$. Cierta tradición, recogida por compiladores como Ibn 'Idāāī (s. XIII) y al-Maqqarī (s. XVII), es la más manejada y divulgada. Según el relato las tropas musulmanas que rinden Córdoba derriban todas las iglesias de la ciudad a excepción de una, localizada en el interior de las murallas. Al-Maqqarī menciona su advocación: Šant B.n.y..n.t. Se interpreta que B.n.y.y.t puede ser la arabización del nombre Vicente, mártir valenciano de difundida memoria en época tardoantigua. El templo se vio obligado a acoger el culto islámico, lo que se tradujo en un reparto del espacio para dar cabida a ambas necesidades. Pasados los años, este edificio, parte iglesia y parte mezquita, ve revisada su situación cuando 'Abd al-Raḥmān I quiere promover la construcción de la aljama. Se entra en una fase de negociación como forma de compensar la ruptura de un pacto previo que, pese a ser leonino para los cristianos (destrucción de todas las iglesias y obligar a compartir la indultada), les amparaba como legítimos posesores de su porción de templo. El emir se comporta con largueza y los cristianos salen de allí con los bolsillos llenos de oro y el permiso para reedificar todas las iglesias que les fueron demolidas en la conquista. Zanjado el asunto, se procedió al derribo del edificio para conformar el solar sobre el que se levantaría la mezquita dinástica.

Esta tradición literaria es la que dio lugar al nacimiento del mito de San Vicente: un magnífico edificio identificado con la catedral preislámica cordobesa (aunque nada se diga en las fuentes a este respecto) que terminó compartido con los musulmanes antes de ser destruido. El principio de la historia se encuentra en una actitud musulmana de enorme impacto para el patrimonio inmueble cristiano ya que supuso la destrucción de todas las iglesias de la ciudad a excepción de ese templo dividido. Esta actitud, se dice, no hacía más que repetir en al-Andalus comportamientos previamente ensayados por los omeyas en otras ciudades. Ahora bien, ¿qué derribó de forma masiva y expeditiva las iglesias de ciudades como Damasco y Córdoba, la pluma de los escri-

\footnotetext{
${ }^{4}$ Nosotros hemos manejado traducciones de los textos árabes originales. Agradecemos a Eduardo Manzano Moreno sus observaciones sobre la naturaleza y transmisión de las fuentes árabes.
} 
tores o la piqueta de las cuadrillas de demolición? Parece ser que la primera. Susana Calvo ${ }^{5}$ opina que Ibn ' $I$ dārī es el que construye este escenario de severa actitud omeya en Córdoba a partir de tradiciones literarias relativas a Damasco en las que también se habla de un episodio de templo compartido previo a la erección de la aljama ${ }^{6}$. Hace ya tiempo ${ }^{7}$ se puso en evidencia que el nacimiento de estas historias es muy posterior a los hechos narrados. Son elaboraciones de memoria sobre aspectos relevantes del pasado pero imprecisos en el momento de ser pergeñadas. Uno de estos aspectos es la fundación de las mezquitas aljamas ${ }^{8}$.

Pero si pasamos del registro documental al material, ¿qué pruebas arqueológicas tenemos respecto a estas olas de destrucción masiva de iglesias? En Córdoba ninguna. En esta ciudad, a día de hoy, tenemos reconocidas como iglesias preislámicas seguras las vinculadas al complejo de Cercadilla. Ninguna de ellas (tres), por lo que podemos extraer de la información suministrada por los excavadores ${ }^{9}$, sufrió en época paleoislámica una destrucción y una posterior reparación. Damasco tampoco aporta información arqueológica que avale el ímpetu destructor omeya. En cuanto a su aljama no se admite que integre en sus muros restos pertenecientes a la iglesia (conocida como San Juan) que se supone se levantaba en ese lugar, al igual que ocurre en Córdoba respecto a San Vicente.

Esta memoria escrita es auténtica como producto histórico pero no puede usarse para historiar sobre los acontecimientos que narra. La memoria material advierte sobre la necesidad de estudiarla desde un enfoque distinto al de suministradora de datos veraces. Estamos ante unos textos eminentemente laudatorios. 'Abd al-Raḥmān I aparece como príncipe piadoso (impulsa la creación de la aljama), íntegro (se sienta a negociar ), paciente (los cristianos rechazaron en primera instancia su oferta y a pesar de ello no recurrió a la fuerza) y magnánimo (com-

5 Calvo, "Les premières mosquées et la transformation des sanctuaires wisigothiques (92H/711-170H/785)", p. 151.

${ }^{6}$ Calvo, “Analogies entre les Grandes Mosquées de Damas et Cordoue: mythe et réalité".

${ }^{7}$ Lammens, "Etudes sur le siècle des omayyades", pp. 269-304.

${ }^{8}$ Calvo, "Las primeras mezquitas de al-Andalus a través de las fuentes árabes (92/711170/785)", p. 171

${ }^{9}$ Hidalgo, El criptopórtico de Cercadilla, análisis arquitectónico y secuencia estratigráfica.

Al-Qantara XXXVI 1, 2015, pp. 11-44 ISSN 0211-3589 doi: 10.3989/alqantara.2015.001 
pensa con una fabulosa cantidad de oro y da el permiso para reedificar las iglesias). La imagen de la iglesia compartida permite ofrecer un escenario en el que el emir puede comportarse de forma elogiable. Los musulmanes, durante décadas, han tenido que vivir una situación de franca incomodidad porque un acuerdo les obligaba a tener que aceptar la presencia cristiana. Pese a disponer de la fuerza que les hubiera permitido revertir la situación no dudaron en soportar estrecheces. Esa estampa que nos presenta el texto, con tarimas colgadas en los muros como forma desesperada de aumentar la superficie congregacional para acoger a un creciente número de fieles, construye una eficaz imagen de situación insostenible. Ahí es cuando interviene el emir y soluciona los problemas. Llega a un nuevo acuerdo que deja libre el terreno para que se levante la mezquita aljama, un edificio real, tangible, que es en definitiva el motor de toda la historia que queda sepultada bajo él.

El relato que dio pie a la forja de un edificio legendario debe ser tomado con todas las cautelas a la hora de intentar deducir importantes aspectos de la materialidad arquitectónica cordobesa a lo largo del siglo VIII. En el dosier documental encontramos más noticias que aluden a la existencia de iglesias en el entorno donde se terminó levantando la mezquita aljama. Estos testimonios abundarían en la idea que trasmite la tradición antes analizada: que el espacio urbano de la mezquita había estado cristianizado con anterioridad con la presencia de edificios religiosos que fue necesario eliminar. En los Ajbār Mầmū' $a$ se dice que durante los enfrentamientos entre yemeníes y muḍaríes en el año 748, varias decenas de miembros de la primera facción fueron juzgados y ejecutados: «[...] en una iglesia que estaba en el interior de la Medina de Córdoba -y hoy es emplazamiento de su Mezquita Aljama-, [...]». Lo escueto de la noticia impide caracterizar el centro de culto (catedralicio, monástico, parroquial). Nada indica que fuera un templo compartido. Manuel Ocaña piensa que la degollina nunca habría tenido lugar en un espacio al que también iban a orar los musulmanes ${ }^{10}$. Al desarrollar esta idea, si la iglesia en cuestión está bajo la mezquita no podía ser otra que la basílica de San Vicente de la otra tradición, por lo cual era necesario recomponer el relato. Al no haber, según Ocaña, una iglesia-mezquita, el templo en el que son ejecutados los facciosos todavía estaría, íntegro, en manos de los cristianos en la fecha del acon-

${ }^{10}$ Ocaña, “La basílica de San Vicente”, p. 349. 
tecimiento (año 748). Se enmienda el guión tradicional al negar que desde el momento de la conquista los musulmanes compartieron una iglesia. De otra fuente deduce Ocaña que hubo una mezquita en este entorno antes de la construcción de la aljama. En 756, mientras 'Abd al-Rahmān I está disputando el poder de al-Andalus, «Abó Otsem fué sitiado en la torre de la mezquita mayor, que estaba en el alcázar [...]». Interpreta Ocaña que la mezquita no estaba en el alcázar, sino en sus inmediaciones, a excepción de su alminar, que era una torre del recinto fortificado. ¿De dónde ha salido entonces esta mezquita si no se admite la presencia, desde la segunda década del siglo VIII, de un templo compartido? Dicha mezquita sería, según Ocaña, la iglesia de las ejecuciones, la cual tuvo que ser expropiada por los musulmanes para convertirla íntegramente en oratorio islámico. En consecuencia, esto tuvo que ocurrir ente 748 y 756. ¿Qué pasó entonces con los cristianos desalojados? La respuesta no la puede encontrar Ocaña en ninguno de los textos, por lo que elabora una teoría tan sugerente como indemostrable. Lo que había era un complejo cristiano de carácter monástico dedicado a San Vicente que sigue en manos de la comunidad de monjes hasta que, en un momento indeterminado de mediados del siglo VIII, les es arrebatada su iglesia para ser transformada en mezquita. Este desalojo fue compensado con el permiso dado al colectivo monacal para que pudiera seguir contando con un espacio cultual. No especifica si se trataba de una iglesia secundaria o de un edificio reconvertido. La relectura que de las fuentes escritas hace este investigador da lugar a un escenario notoriamente distinto al que presentaba Ibn 'Idāaì. A pesar de ello, da por buenos algunos aspectos de la tradición integrándolos en su relato: la advocación de la iglesia, San Vicente; y dar por seguro que la construcción de la aljama supuso la destrucción de una iglesia que estaba siendo usada. Según Ocaña, no sería una iglesia repartida entre los dos cultos desde la época de la conquista, sino otra iglesia cercana a la de San Vicente.

Hay otra fuente documental, que Ocaña no conoció, en la que tenemos noticias sobre iglesias con las que se negocia en el contexto de la construcción de la mezquita. En la obra anónima Dikr bilād al-Andalus, de entre mediados del siglo XIV y comienzos del XV, se lee: «En el año 169 (785-786) el imán 'Abd al-Raḥmān al-Dājil compró a los cristianos dimmíes el solar de la aljama de Córdoba, donde se alzaba una iglesia cristiana. Pagó por él cien mil dinares y lo añadió al patio de la 
mezquita ${ }^{11} \gg$. No se dice que el edificio estuviera compartido. Tampoco hay alusión a ningún complejo cristiano formado por varios inmuebles. Coincide con la versión de Ibn 'Idāāī y al-Maqqarī en la fecha y en el montante de la indemnización. También es el emir el que aparece como impulsor de la compra. Ninguna mención al permiso dado para reparar las pretendidas iglesias derribadas años atrás. Según Manuel Nieto este texto es argumento para defender que bajo la mezquita estaría el complejo episcopal cordobés ${ }^{12}$. La iglesia mencionada en el relato no sería la de San Vicente, la cual había sido arrebatada totalmente por los musulmanes (idea original de Ocaña), sino otra cercana que formaría parte del grupo episcopal. En nuestra opinión, esta noticia aporta su cuota de contradicción histórica que viene a sumarse a las del resto. Dice el relato que la iglesia se erigía en el mismo lugar que la mezquita pero, cuando se compra y amortiza, el espacio liberado se añade como patio y no como solar para la sala de oración. Esto implica que había ya hecha una mezquita, sin patio, prácticamente pared con pared con una iglesia. Dicha mezquita, por fuerza, tenía que ser ya la de 'Abd al-Rahmān I. Ahora bien, el proyecto original de la primera mezquita aljama integra sin género de dudas la sala hipóstila y el patio, lo que hace entrar en colisión el texto con la realidad material.

También queremos dar cabida a las noticias relativas a mezquitas previas a la aljama. La presencia de mezquitas pre-aljama es dada a conocer bajo situaciones excluyentes entre sí de forma similar a lo que ocurre con la colección de noticias referidas a las iglesias. Tenemos por un lado el texto recogido por Ibn 'Id̄ārī y al-Maqqarī. Según éste, los musulmanes contaron con un espacio para orar desde el momento de la conquista al habilitar para tal efecto la mitad de una iglesia. No hay por tanto obra nueva. En cambio, según Ibn Hayyān (Muqtabis II) que se basa en al-Rāzi ${ }^{13}$, los musulmanes fundan desde los cimientos un oratorio de nueva planta:

${ }^{11}$ Molina (trad.), Dikr bilād al-Andalus, II, p. 123.

12 Nieto, La catedral de Córdoba, p. 48.

13 'Alī Makkī y Corriente (trads.), Crónica de los emires Alhakan I 'Abdarrahman entre los años 796-847, Muqtabis II-1, p. 173. Que la fuente primaria de esta noticia sea al-Rāzī (888-955) hace sospechar que, en la época en la que escribe, todavía no se contemplaba la implicación de edificios religiosos cristianos en los momentos fundacionales de la aljama. Por su parte, Ibn Hayyān (987-1075), cronista referencial manejado hasta la saciedad por compiladores posteriores, tampoco lega informaciones sobre posibles iglesias 
Dijo al-Rāzì: El emir 'Abd al-Raḥmān b. al-Ḥakam amplió la mezquita aljama de Córdoba $[\ldots]$ Su ampliación era visible en la dirección de la alquibla para quien entrase en ella, patente entre lo que queda de la primera construcción de su bisabuelo, 'Abd al-Raḥmān b. Mu'āwiya, [...], sobre los cimientos de los árabes conquistadores de la Península, que fundaron esta mezquita bendita.

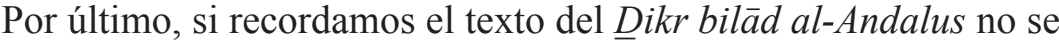
hace alusión a ninguna mezquita (ni compartida ni exclusiva) que fuera necesario derribar para levantar la aljama.

En definitiva, de la colección documental manejada se desprenden noticias que tienen que ver tanto con iglesias como con mezquitas previas a la aljama. Es imposible conciliar los datos pues unos contradicen a otros dando como resultado escenarios enfrentados. Llegados a este punto, la arqueología es una disciplina histórica que aporta su propio registro informativo, el material, que puede ayudar a resolver las dudas.

\section{La arqueología}

Las excavaciones emprendidas por don Félix Hernández nunca fueron publicadas. El material informativo disponible, además, es escaso. En los últimos años se han producido meritorios intentos (Marfil, Fernández-Puertas, Bermúdez, Sánchez Ramos) ${ }^{14}$ para poner en claro lo que dejó Félix Hernández en su archivo personal, legado por su familia al Museo de Córdoba. La información de archivo no es muy prolija y de ello se ha querido hacer un problema a la hora de interpretarla, tanto para nosotros como para las personas que en origen la produjeron a raíz de las exploraciones de subsuelo. En otras palabras, nada se tiene por concluyente y por tanto es posible someter el asunto a revisiones a partir de nuevos enfoques interpretativos.

afectadas por las obras. Ibn 'Idāāin, ya en el siglo XIII, recoge el asunto del templo compartido, por lo que la aparición de iglesias a la sombra de un gesto dinástico de enorme peso simbólico y material parece ser una aportación tardía que deberá ser interpretada en el contexto histórico en el que pudo ser alumbrada.

${ }^{14}$ De todos los trabajos sin duda es el de Fernández-Puertas (Mezquita de Córdoba. Su estudio arqueológico en el siglo $X X$ ) el más exhaustivo y el que aporta mayor cantidad de datos y material gráfico original (dibujos, fotografías, planos). 
Se ha hecho inevitable tener que admitir que el arquitecto se equivocó al interpretar sus excavaciones. Nadie, con esto, ha querido empañar la memoria de un destacado estudioso de la arquitectura islámica que cuenta con valiosos trabajos referenciales ${ }^{15}$. La culpa se hace recaer en la forma de trabajar de una época en la que el desarrollo de herramientas instrumentales y metodológicas era deficiente. Hay una falta de sistematización de la información, pero ¿hasta qué punto esto invalida las conclusiones a las que se llegó? Por desgracia, las opiniones que le llevaron a determinar que el paisaje monumental inmediatamente anterior a la construcción de la mezquita distaba mucho de ser tan espléndido como se auguraba nunca fueron fijadas en un texto. Tenemos no obstante un testimonio muy valioso, que ofrece Ana María Vicent, basado en conversaciones personales mantenidas con Hernández:

según nos comunicó don Félix en distintas ocasiones los restos que allí encontró,
y que pasó a un minucioso plano, le dejaron algo perplejo acerca de la existencia
de dicha iglesia [San Vicente] pues, aunque se presenten en una dirección este-
oeste [se refiere a ciertos muros aparecidos en la sala de oración], lo que pudiera
ser cimentación de la nave central ofrece para ésta una anchura ridícula, aparte
de que no se descubrieron vestigios de la cabecera y de ningún elemento carac-
terístico de la estructura propia de un edificio litúrgico paleocristiano o visi- $_{\text {godo }^{16} \text {. }}$

Se entiende que dichos restos pertenecían a un edificio que era inmediatamente anterior a las obras de la mezquita, el que tuvo que ser derribado en el siglo VIII. Bajo él aparecían otras estructuras, de mejor calidad técnica y riqueza artística (presencia de mosaicos), pero no tenían nada que decir porque estaban amortizadas mucho tiempo atrás. Manuel Ocaña, que contó con el testimonio directo trasmitido por Hernández, lo explica de una forma tan sencilla como demoledora desde un punto de vista estratigráfico: «Tales restos han sido hallados entre los niveles del suelo romano, también descubierto, y el musulmán de la Mezquita, por lo que parece corresponder a una obra visigótica ${ }^{17} \gg$. ménez".

15 Fernández-Puertas, "Bosquejo sobre la labor científica de Don Félix Hernández Gi-

${ }^{16}$ Vicent, "Perfil científico y humano de D. Félix Hernández", p. 176.

17 Ocaña, "La basílica de San Vicente", p. 361. 
Hubo algún testigo que sí dejó por escrito sus impresiones. Nos referimos a una figura de capital importancia en nuestra historiografía: don Manuel Gómez-Moreno. Este arqueólogo fue el verdadero impulsor de las exploraciones en el subsuelo ${ }^{18}$. El más brillante especialista de la época en lo tocante a la arquitectura paleocristiana y visigoda emitió su juicio respecto a los hallazgos:

Se ha explorado, ha pocos años, en el subsuelo [de la mezquita] para rebajar el pavimento sin descubrir nada que pudiera corresponderle [a la supuesta iglesia de las fuentes escritas]. A gran profundidad aparecen mosaicos romanos y cimientos de casa; encima, a unos 55 centímetros del piso moderno, la cepa de un edificio ruin, con solería de hormigón y paredes de mampostería mala [...] y, ya en el patio, a dos de profundidad, la ruina de otro edificio romano tardío: gran pórtico rematado en exedras, habitaciones a su parte oriental y delante cinco columnas, con capiteles de tipo corintio degenerado [...] fustes de pudinga mal redondeados y basas áticas: ni su situación ni su aspecto corresponden con lo que se busca ${ }^{19}$.

Ambos testimonios son bastante elocuentes respecto a lo esperado y lo encontrado. Sin embargo, dentro del círculo investigador cordobés hubo personas, como Manuel Ocaña y Samuel de los Santos Gener, que se esforzaron por salvar al malherido mito frente a la aparente indiferencia mostrada por Hernández y Gómez-Moreno. Se aferran los cordobeses a la posibilidad de que algunas de las estructuras exhumadas estuvieran asociadas a iglesias preislámicas. Ocaña encuentra pruebas materiales de su teoría al interpretar que cierto nicho existente en un muro sería el mihrāb hecho por los musulmanes cuando arrebatan una iglesia para convertirla en mezquita. Samuel de $\operatorname{los}_{\text {Santos }}{ }^{20}$ ve en la estructura encontrada en el patio una iglesia a la que le aparecen varios ábsides en su lado norte, tal como vemos en un croquis hecho por este autor (figura 2).

${ }^{18}$ Cuenta Antonio Fernández-Puertas, según testimonio del propio F. Hernández, que fue Gómez-Moreno quien urdió la intervención arqueológica con el objetivo de buscar la iglesia de San Vicente. Gómez-Moreno, durante su paso por la Dirección General de Bellas Artes (1930), designó a Hernández comisionado del arquitecto de la Sexta Zona, antesala para su nombramiento como conservador de la Mezquita y por tanto habilitado para excavar en el edificio (Fernández-Puertas, Mezquita de Córdoba, pp. 21-23).

${ }_{19}$ Gómez-Moreno, El arte árabe español hasta los almohades, p. 19.

20 Santos-Gener, "Las artes en Córdoba durante la dominación de los pueblos germánicos". 


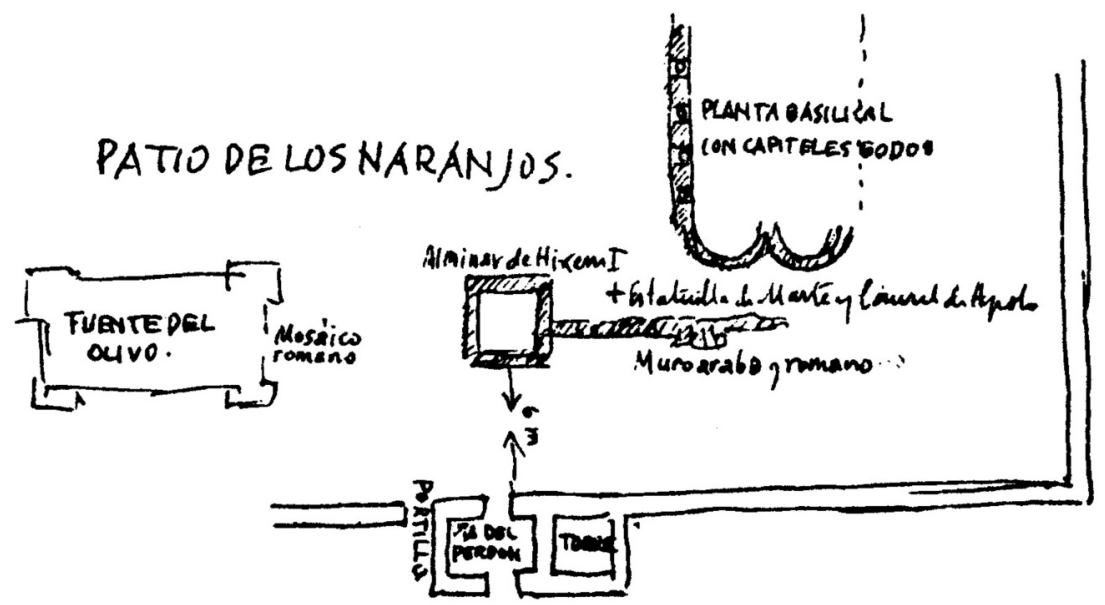

Figura 2. Croquis realizado por Samuel de los Santos Gener de los hallazgos hechos por Félix Hernández en el patio, publicado por Pedro Marfil,

"Córdoba de Teodosio a Abd al-Rahmán III".

Los capiteles allí encontrados, sin esgrimir fundamento tipológico alguno, se proclaman como visigodos para dar mayor credibilidad a su propuesta de iglesia tardoantigua. Esta propuesta fue rechazada desde el primer instante por Hernández:

pero, por conversaciones con don Félix y por la planta y alzado que dibujó, debe desecharse la idea [de la iglesia de Samuel de los Santos] aunque creemos, como hipótesis personal [quien escribe es Ana María Vicent], que tales estructuras pueden pertenecer ciertamente a época tardorromana ${ }^{21}$.

En las campañas de los años 30 no sólo se exhumaron restos de edificios; también se recuperaron algunas piezas con contenido inequívocamente cristiano $^{22}$. Hoy se encuentran expuestas, junto a otros objetos,

21 Vicent, "Perfil científico y humano de D. Félix Hernández", p. 177.

22 Sánchez-Velasco, Elementos arquitectónicos de época visigoda en el Museo Arqueológico de Córdoba. Arquitectura y urbanismo en la Córdoba visigoda. 
en el llamado Museo de San Vicente ${ }^{23}$. Nieto ${ }^{24}$ sólo acepta a tres de ellos como procedentes del subsuelo: una placa nicho con venera y crismón, una pila decorada con crismón, y un fragmento de sarcófago constantiniano. Se pregunta Caballero si estas piezas pertenecían a supuestos edificios cristianos allí radicados o son restos de spolia aportados en la construcción de la mezquita ${ }^{25}$. Ni Hernández ni Gómez-Moreno las mencionaron como posibles indicios de la existencia de la buscada iglesia de San Vicente.

En la década de los 90 del siglo pasado se tuvo la oportunidad de volver a actuar arqueológicamente en la mezquita. Los trabajos, dirigidos por Pedro Marfil, consistieron, entre otras cosas, en la apertura en el patio de una zanja en paralelo a la fachada norte. La trinchera del patio tiene el interés de haber sacado a la luz diferentes niveles de uso anteriores a la construcción de la mezquita. Encuentra Marfil tres niveles superpuestos, cada uno de ellos con la presencia de estructuras arquitectónicas diferenciables entre sí por las técnicas y materiales constructivos, por las orientaciones de los muros y por las cotas. El nivel inferior, por tanto el más antiguo, está definido por unos muros realizados en opus vittatum mixtum (combinación de mampostería y ladrillo). El intermedio, que se cimenta sobre lienzos arrasados de la primera fase, presenta fábricas que se consideran de opus cuadratum (sillería) si bien los bloques, reutilizados, son un mero zócalo que sirve de base para alzados en tapial. El nivel superior, el más moderno de la secuencia y por tanto el que estaba aflorado cuando se inician las obras de la aljama, cuenta con muros constituidos por un zócalo de mampostería sobre el que se levantarían paredones de tapial. Aparte

${ }^{23}$ El Museo de la Basílica de San Vicente es algo más que un espacio expositivo que nos habla de los precedentes históricos (cristianos) del lugar en el que se levantó el edificio más emblemático de al-Andalus. Es, sobre todo, la musealización de un discurso historiográfico tendencioso en buena parte espoleado por las reclamaciones hechas en los últimos años por la Junta Islámica con el objetivo de poder usar la mezquita como lugar de oración (Ruggles, "La estratigrafía del olvido: la gran mezquita de Córdoba y su legado refutado", pp. 27-28). Son elocuentes las palabras de Luis Recio Mateo (Diario de Córdoba, 20 de enero de 2005) unos días antes de la inauguración del museo: «Será esta inauguración, la que desde ahora permitirá visualizar in situ el carácter sagrado cristiano del lugar donde se encuentra el monumento islámico más importante de España». [...] «Desde ahora, no podrá explicarse la Mezquita árabe sin mencionar antes su origen histórico cristiano».

${ }^{24}$ Nieto, La catedral de Córdoba.

${ }^{25}$ Caballero, “'Impacto' del Islam en la arquitectura cristiana que se conservó o se reconstruyó en al-Andalus (o bajo domino musulmán)", p. 29. 
de trabajar en el subsuelo, de la mezquita Marfil fue el primero en hacer una revisión crítica del archivo de Hernández. Al cruzar la información obtenida en sus excavaciones con la del archivo da un importante paso a la hora de reconstruir la secuencia vista por Hernández. Los edificios con zócalo de mampostería parecen corresponder con el «edificio ruin» de Gómez-Moreno, el que sin duda tuvo que ser derribado por ser la fase presilámica más moderna. Los muros de zócalo de sillería del nivel intermedio, por su orientación, serían asimilables a otros muros de idéntica dirección encontrados por el arquitecto en la sala hipóstila, que contaban con algún pavimento musivo. Por último, al igual que en el patio, Hernández encontró fábricas de opus vittatum mixtum que tenían asociados otros restos de suelos en mosaico. En definitiva, se documenta una secuencia de al menos tres horizontes histórico-constructivos anteriores a la mezquita tanto dentro como fuera.

En los últimos años se ha reactivado el asunto del precedente cristiano de la mezquita. La propuesta de Marfil es la más entusiasta al proponer una rica secuencia de actuaciones monumentales cristianas antes de la implantación del edificio que sellaría sus despojos:

En general lo que puede deducirse del estudio historiográfico es que F. Hernández no llegó a identificar como paleocristianos los restos anteriores a época visigoda, perdiéndose por tanto la perspectiva de la evolución de San Vicente y haciendo pensar a este arquitecto que la realidad material era muy distinta a lo esperado tras la lectura de las fuentes literarias ${ }^{26}$.

En la explicación de Marfil vemos surgir iglesias desde los niveles más profundos, los mismos en los que Gómez-Moreno localizaba las «casas romanas». Los muros de opus vittatum mixtum formarían ahora parte de un primigenio centro de culto cristiano del que se dan dos interpretaciones y cronologías distintas. En un artículo del año 2000 piensa que era una iglesia de carácter martirial erigida en el siglo $\mathrm{V}$, que existía en ese área urbana antes de la instalación en ella del complejo episcopal ${ }^{27}$. Unos años después ${ }^{28}$ sostiene que sería de mediados del siglo VI. No deja claro si sigue pensando que era una iglesia mar-

${ }^{26}$ Marfil, "Córdoba de Teodosio a Abd al-Rahmán III", p. 125.

${ }^{27}$ Marfil, "Córdoba de Teodosio a Abd al-Rahmán III", p. 124.

28 Marfil, "La sede episcopal de San Vicente en la santa iglesia Catedral de Córdoba", pp. 41-42. 
tirial que luego es usada como catedral o bien su construcción se hace en el marco del surgimiento de la sede episcopal. El único dato positivo que aporta para defender su condición de templo es la presencia de ladrillos hechos con un molde que ha dejado impreso un crismón junto al texto Ex of(ficina) Leonti (CIL II $\left.{ }^{2} / 7,698\right)$. J. Stilow estima que esta inscripción podría moverse en un amplio arco cronológico que iría desde el 500 al 700. La presencia de ladrillos con Crismón no puede por sí misma ser una prueba definitiva para afirmar que estamos en un edificio de culto ${ }^{29}$. Conocemos construcciones que con seguridad no son iglesias en las que también hay crismones, como en un hórreo de Oretum (Granátula de Calatrava, Ciudad Real; CIL II2/5,513), por no hablar de multitud de objetos cerámicos y metálicos que portan este signo $^{30}$. Su presencia tiene un carácter salutífero, no es una forma de señalar un lugar sacralizado. Lo mismo puede significar en el caso que nos ocupa, un espacio seguramente residencial. Fuera de los ladrillos no hay ningún indicio que delate el desarrollo de la liturgia cristiana: ni espacios que definan ámbitos celebrativos ni huellas de mobiliario litúrgico.

El segundo nivel constructivo, que define como de opus cuadratum, estaría igualmente integrado por un conjunto de estructuras arquitectónicas pertenecientes a una iglesia que amortizaría a la anterior o que la transformaría de forma notable. La fecha en la segunda mitad del siglo VI, lo que quiere decir que sólo sería unas décadas posterior a la primitiva, de mediados de esa misma centuria. La técnica constructiva de esta fase y la presencia de mosaicos le remiten a otro edificio cordobés a pocas calles de distancia excavado por Lauro Olmo y el propio Marfil $^{31}$. Se trata de la llamada iglesia de Santa Catalina del convento de Santa Clara. Al considerar Marfil que lo excavado en el abandonado convento era una iglesia puede argumentar que el edificio de la mezquita era igualmente un templo. Las pruebas que aporta Marfil para defender la existencia de la iglesia de Santa Catalina no son en absoluto convincentes. Coincidimos con las críticas que en este sentido hacen

\footnotetext{
29 Agradecemos a Helena Gimeno la información e indicaciones que nos ha suministrado sobre este asunto así como al resto de personas del CIL que amablemente nos han enviado fichas e imágenes.

${ }^{30}$ Ripoll y Darder, "Frena equorum. Guarniciones de frenos de caballos en la antigüedad tardía hispánica”.

31 Marfil, "La iglesia paleocristiana de Santa Catalina en el convento de Santa Clara". 
María Ángeles Utrero ${ }^{32}$ y Luis Caballero ${ }^{33}$ a la propuesta. El empeño de Marfil por ofrecernos la iglesia en Santa Clara se inscribe en su teoría sobre la presencia en Córdoba del poder imperial bizantino cuyo paso, pese a ser fugaz, se tradujo en una importante acción monumental en la parte sur de la ciudad que haría de ella la urbe «más oriental de Hispania ${ }^{34}$. La impronta bizantina, en lo artístico, vendría dada únicamente por los pavimentos musivos, tanto en Santa Clara como en la mezquita, cuyas características formales se arrastran hasta mediados del siglo VI (según paralelos con los mosaicos de las basílicas baleares). Si en Santa Clara es más que dudoso que podamos hablar de una iglesia, queda maltrecho el argumento de la identidad tecnológica como prueba de identidad funcional. En todo caso, que en Santa Clara y en la mezquita encontremos estructuras semejantes sería indicativo de que en un momento de la historia de Córdoba se están llevando a cabo actuaciones edilicias que pueden ser sincrónicas en esta parte de la ciudad. La fecha, los motivos y las consecuencias de estas acciones están todavía por determinar.

Respecto al nivel preislámico superior, en consecuencia el inmediatamente anterior a la aljama ${ }^{35}$, también lo considera Marfil escenario de una nueva acción constructiva de corte religioso. Le otorga una cro-

${ }^{32}$ Utrero, "Las iglesias cruciformes del siglo VII en la Península Ibérica. Novedades y problemas cronológicos y morfológicos de un tipo arquitectónico", pp. 143-144.

${ }_{33}$ Caballero, "'Impacto' del Islam en la arquitectura cristiana”, p. 30.

${ }^{34}$ Marfil, "Córdoba de Teodosio a Abd al-Rahmán III", p. 124.

35 Este nivel, en su última fase de uso, puede considerarse propiamente islámico aunque previo a la aljama, como lo demuestra la reparación parcial de un suelo de opus signinum. En dicha reparación (un empedrado) se han recuperado un buen número de monedas musulmanas (feluses) extraviadas por personas que se movían en este entorno y hacían circular el dinero (Frochoso, "Las monedas encontradas en la excavación de la Catedral de Córdoba"). Es también de interés el resultado arrojado por una cata abierta por Hernández en la llamada puerta de San Esteban. Se encontró un pozo negro amortizado y sellado por la obra de la mezquita que perteneció a un ambiente doméstico del siglo VIII en virtud del lote de cacharros cerámicos encontrado en él (cántaros, jarros, redomas, ollas, orzas, escudillas, un bacín). Ha sido estudiado por Fernández-Puertas y Marinetto (Fernández-Puertas, Mezquita de Córdoba, pp. 80-84). Lo que nos transmite el registro del subsuelo es que esta área urbana era un lugar vivo en la Córdoba musulmana de las primeras décadas, reafirmado con la presencia, a poca distancia, del alcázar omeya. La cuestión es si estamos ante un sector ciudadano cristianizado de antiguo con la existencia de edificios representativos (religiosos y civiles) que está siendo transformado o bien se puede hablar de un ámbito ciudadano que ya está islamizado (al menos en lo político y social) en la segunda mitad del siglo VIII y que por eso será el escenario elegido para levantar la mezquita. 
nología del siglo VII. No parece que asuma Marfil que esta fase hubiera arrasado por completo a la anterior sino que simplemente la reforma. Sus observaciones estratigráficas en la zanja del patio, no obstante, invitan a pensar en la primera opción:

La siguiente fase presenta muros con zócalo de mampuesto y alzados de tapial, que en parte reutilizan los muros de la fase anterior y en parte modifican el trazado de los edificios preexistentes. Elevándose nuevamente el nivel de suelo por encima de los restos anteriores ${ }^{36}$.

Parece evidente que se trata de una superposición de fábricas desde los fundamentos. Los restos de un suelo hidráulico sirven de argumento para hablar de un espacio bautismal obviando importantes detalles: que no se reconoce la arquitectura que debía albergar la pileta y que el tamaño de esta $(7 \times 3,8 \mathrm{~m})$ es llamativamente grande en comparación con otras conocidas.

El reconocimiento de espacios religiosos cristianos por parte de Marfil no se limita al interior. Según él en el patio hay otra iglesia, representada por una de las estructuras arquitectónicas encontradas por Hernández. Da como correcta la interpretación realizada por Samuel de los Santos, según la cual se trataba de un edificio basilical con cabecera triabsidada orientada al norte: «En el patio de los naranjos se localizó un edificio de planta basilical con cabecera triabsidada ${ }^{37}$ ». Asume sin crítica la fecha de la segunda mitad del VI que apunta de los Santos a partir de la datación de los capiteles encontrados al tiempo que elude la descripción de Gómez-Moreno en la que es obvio que estamos ante un atrio porticado y no ante una basílica rematada con varios ábsides.

Hay, por otra parte, importantes argumentos en contra de la existencia de lugares de culto cristiano en cualquiera de los niveles constructivos. Por un lado están las orientaciones de las estructuras arquitectónicas encontradas. Cabría esperar ver unos edificios orientados de este a oeste como es habitual. Los muros encontrados corren en distintas direcciones: unos de norte a sur y otros de sureste a noroeste. Mucho más determinante es el dato negativo representado por la ausencia de enterramientos, algo clamorosamente extraño en entornos

${ }^{36}$ Marfil, "La basílica de San Vicente en la catedral de Córdoba", p. 194.

37 Marfil, "Córdoba de Teodosio a Abd al-Rahmán III", p. 127. 
cristianos sacralizados. Podría pensarse que la no localización de la inevitable nebulosa de enterramientos asociados a estos edificios se deba a una cuestión de azar arqueológico ya que, las excavaciones de Hernández, no afectaron a toda la superficie que ocupa la mezquita de 'Abd al-Raḥmān I. Esta presunción queda desacreditada desde el momento en el que los muros encontrados se interpretan como restos de una iglesia o iglesias, por lo que, de haber tumbas, tenían que estar allí y no en los alrededores.

La interpretación de Marfil viene a ser la materialización de la teoría de Ocaña: los cristianos fueron desposeídos de una iglesia que fue convertida, toda, en mezquita (que se encuentra bajo la actual sala de oración), pero pudieron seguir practicando sus ritos en un templo próximo (que está en el patio), hasta que se erige la aljama y, ambos edificios, son demolidos quedando enterrada la memoria cristiana del lugar. Marfil, aparte, presenta desde el registro arqueológico una rica secuencia de promociones arquitectónicas cristianas antes de que pasara el vendaval musulmán. El área de la mezquita, ahora el área de San Vicente, tuvo que ser en época preislámica un enclave urbano relevante de la cristiana Córdoba como atestigua la sucesión de intervenciones monumentales. En este punto es donde se separa, por una sola vez, del discurso de Ocaña. No estaríamos ante un monasterio urbano como pensaba Ocaña sino ante el conjunto de edificios que formaban el complejo episcopal de la ciudad.

\section{Buscando el conjunto episcopal}

Si la iglesia de San Vicente vuelve a tener actualidad historiográfica se debe a los intentos por localizar, bajo la mezquita, el inevitable complejo episcopal preislámico que hubo de existir en Córdoba. En las últimas décadas, los estudios dedicados a la tardoantigüedad han tenido un destacado desarrollo en el ámbito científico internacional. Muchas de las ciudades de fundación clásica siguieron estando habitadas en los siglos V, VI, VII. Hacia esas centurias y lugares se ha dirigido la atención. El proceso de cristianización de las ciudades supuso la aparición de edificios de prestigio vinculados a los poderes confesionales. Entre ellos estarían los conjuntos episcopales que generarían nuevos polos de desarrollo urbano tras la pérdida de centra- 
lidad de los antiguos espacios forenses. La localización de estos complejos se hace inevitable y necesaria para ilustrar el nuevo fenómeno urbano.

La gran cantidad de antiguas ciudades que tuvieron obispados en la península ibérica ofrece un elevado número de potenciales escenarios en los que buscar este tipo de establecimientos. Córdoba es uno de ellos. El yacimiento de Cercadilla, en su momento, arrojó información arqueológica sobre la evolución de esta parte de la ciudad desde los siglos tardoantiguos hasta época medieval cristiana. Por primera vez se encuentran en Córdoba inequívocos restos materiales pertenecientes a centros de culto cristiano. ¿Se había encontrado el complejo episcopal? Pedro Marfil lo cree asín ${ }^{38}$ pero su opinión se enfrenta a otras que lo niegan (Caballero, Bermúdez y Sánchez). Su ubicación suburbana no sigue la tendencia documentada arqueológicamente en otras ciudades, con los edificios episcopales en el interior del perímetro de las murallas. La presencia de obispos enterrados en Cercadilla (lápida de Lampadio del 549 y el anillo de un obispo llamado Sansón) ${ }^{39}$ no son argumentos contundentes para localizar allí el episcopado. Es posible que estos obispos hubieran querido ser inhumados en algún templo de carácter martirial, un tipo de iglesias periurbanas que presentan nutridas necrópolis generadas por la atracción que ejercían las reliquias que albergaban. El ejemplo de la basílica de Santa Eulalia de Mérida sería

38 Marfil, en "El complejo cristiano de Cercadilla (Córdoba)", sostiene que Cercadilla es una empresa auspiciada por el obispo Osio en el siglo IV. La opinión de este arqueólogo es discutida por otros autores en lo tocante al momento fundacional y al uso funcional del monumental complejo. Javier Arce-Martínez, en "Emperadores, palacios y villae (a propósito de la villa romana de Cercadilla, Córdoba)" y Rafael Hidalgo, en El criptopórtico de Cercadilla, aunque desde posturas interpretativas diferentes, rechazan que el criptopórtico pudiera ser una acción emprendida por Osio con el objetivo de crear un complejo cristiano monumental. Piensan ambos que se trata de un proyecto edilicio de carácter civil que, en efecto, en una fase posterior de uso fue reacondicionado en parte para la práctica religiosa cristiana. Por otro lado, Marfil acepta que la catedral cordobesa de inicios del siglo VIII se encontraba en el mismo lugar que luego ocupó la mezquita, lo que significa que se tuvo que producir un traslado desde la sede original (Cercadilla) hasta la parte sur de la ciudad intramuros. Propone que esta mudanza, sin aportar ningún dato que la avale, tuvo lugar a mediados del siglo VI. El clima de enfrentamiento en la ciudad derivado de las luchas entre Córdoba y Toledo es lo que recomienda al obispado buscar el amparo de las murallas. Tras la reubicación de la sede aparecen por allí los bizantinos, quienes estimulan en el sector meridional de la urbe acciones monumentales que dejan traslucir renovadas influencias artísticas orientales traídas por ellos.

${ }^{39}$ Hidalgo y Marfil, "El yacimiento arqueológico de Cercadilla: avance de resultados”. 
paradigmático. El denominado, por los arqueólogos, edificio G de Cercadilla también posee una densa necrópolis con un largo recorrido histórico en el que hay una importante intensificación de su uso del siglo VIII en adelante. La balanza historiográfica se inclina hacia la interpretación de Cercadilla como un complejo religioso suburbano, reacondicionando para tal fin edificios civiles previos, que se relaciona con el culto a santos mártires locales: San Acisclo para Hidalgo y San Zoilo para Marfil.

Descartada la opción extramuros hay que meterse a buscar dentro. Las excavaciones de las últimas décadas en Córdoba han aportado conocimiento material de la ciudad en los siglos tardoantiguos ${ }^{40}$. Se observa que los antiguos espacios representativos del urbanismo romano cordobés (foro, teatro, templo-circo) parecen inutilizados en el siglo IV y pasan a una fase de reocupación popular con la aparición de modestas unidades domésticas. De edificios cultuales cristianos no hay rastro, por lo que debería ser otra parte de la ciudad la que, en época tardoantigua, diera muestras de un dinamismo urbano que se vería potenciado con la instalación de los edificios episcopales. Mientras que los pretéritos lugares centrales dan muestra de recesión las excavaciones en la parte sur de la ciudad ofrecen testimonios de continuidad y cierta vitalidad. Parece que el peso de la vida urbana se desplaza en dirección al río dejando atrás las osamentas de las monumentales estructuras públicas que pasan a convertirse en suministradores de material constructivo para los nuevos edificios principales. La interpretación histórica termina por acordonar una parte de la ciudad anticipando que ha de ser allí donde se tienen que buscar y encontrar los restos de los edificios que conformaban el grupo episcopal. Hasta ahora las modernas excavaciones no han dado con ningún resto perteneciente a una iglesia en esta zona. Ya hemos expresado las enormes dudas que provoca la llamada iglesia de Santa Catalina. Pero no todo está pendiente de futuras exploraciones. Siempre se puede volver a mirar en el subsuelo de la mezquita.

Especialistas como J.M. Bermúdez e I. Sánchez, aparte de Marfil, han dirigido su atención a las viejas excavaciones. La propuesta de Ber-

40 Aportaciones recientes las encontramos en Dupré (ed.), Las capitales provinciales de Hispania, 1, Colonia Patricia Corduba y Vaquerizo y Murillo (eds.), El anfiteatro romano de Córdoba y su entorno urbano. Análisis arqueológico (ss. I-XIII). 
múde ${ }^{41}$ es la más original ya que, en vez de perseguir iglesias, presenta un edificio que, integrado en el complejo, estaría destinado a funciones representativas. Sería en su opinión una episcopalis audientia, un lugar específico de recepción diferente a la propia residencia del obispo. Los restos de esta fábrica serían los localizados por Hernández en la excavación del patio: la estructura porticada rematada en sus extremos por ábsides o exedras. Este atrio era la entrada de un edificio notable que Fernández Puertas ${ }^{42}$, previamente, había restituido parcialmente a partir de la información de Hernández (figura 3). Es un edifico de buen tamaño provisto de un atrio que, como apunta Bermúdez aportando numerosos ejemplos de un amplio arco espacio/temporal mediterráneo, tendría un carácter representativo. Pero no sabemos de cuándo ni con qué función. En los planos que ofrece Bermúdez parece deducirse una secuencia de varias acciones constructivas-destructivas (figura 4). El edificio del atrio, orientado norte-sur, parece que tiene debajo otras estructuras anteriores con otra dirección. Por otra parte, se ve que la exedra meridional del atrio es atacada por otros muros de distinta orientación que se pueden asimilar a los que se encontró en la zanja del patio: los de zócalo de mampostería y alzados de tapial que eran los inmediatamente anteriores a la mezquita y que Hernández también localizó en la sala de oración. La diferencia de cotas entre estos muros y los del atrio (a dos metros del suelo actual según Gómez-Moreno) nos llevan a pensar que ese edificio estaba amortizado antes del siglo VIII. La propuesta de Bermúdez, aunque sugerente, hace más complejo el panorama edilicio ya que, aparte de la por él llamada episcopalis audientia, tendría que aparecer la propia residencia del obispo, amén de otros edificios residenciales y de servicio sin olvidar, ni mucho menos, la iglesia catedral y el baptisterio. ¿Dónde están todos?

${ }^{41}$ Bermúdez, "El atrium del complejo episcopal cordubensis. Una propuesta sobre la funcionalidad de las estructuras tardoantiguas del patio de la mezquita de Córdoba".

${ }^{42}$ Fernández-Puertas, Mezquita de Córdoba, pp. 144-150. 

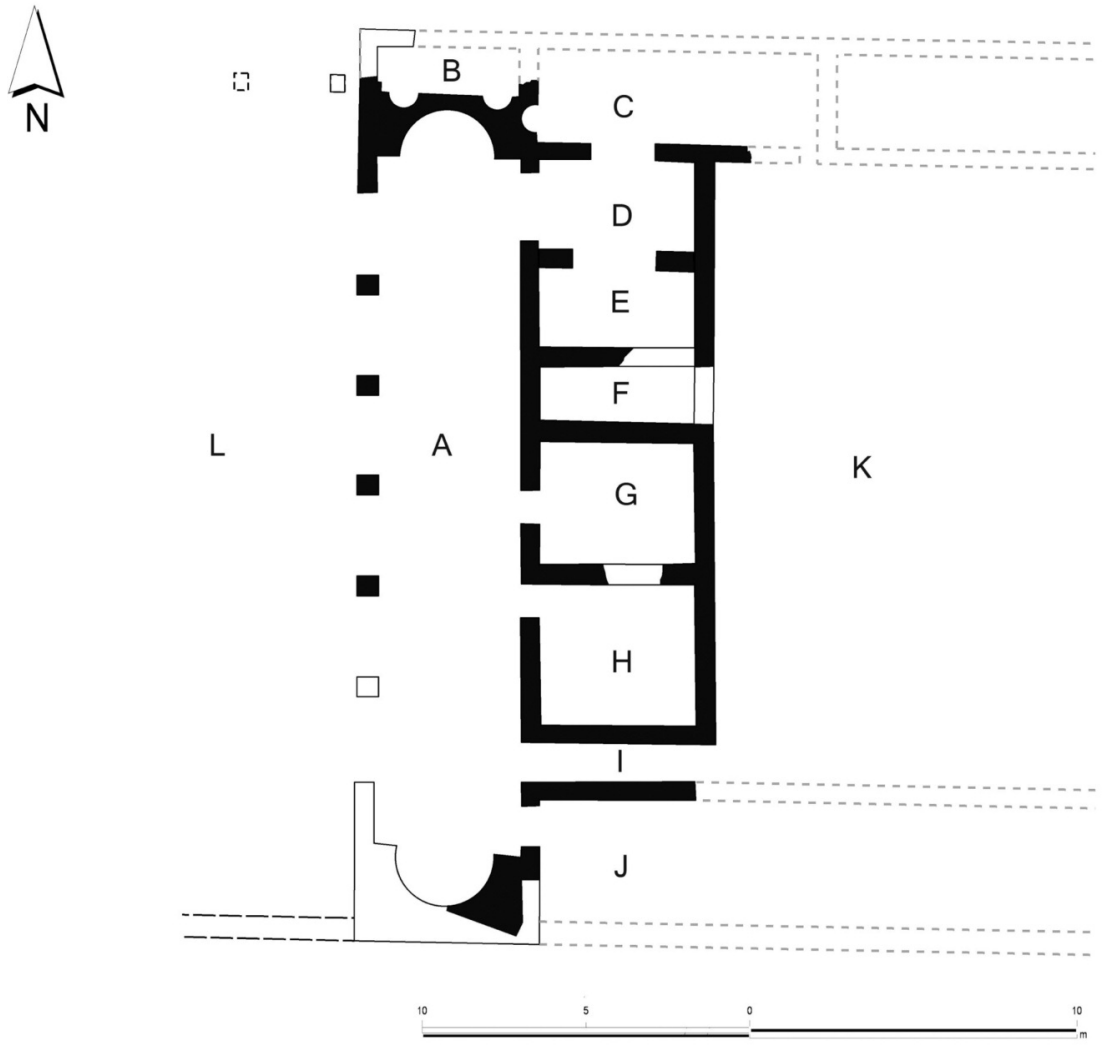

Figura 3. Restitución parcial del edificio provisto de atrio encontrado por Félix Hernández en el patio, según José Manuel Bermúdez, "El atrium del complejo episcopal cordubensis. Una propuesta sobre la funcionalidad de las estructuras tardoantiguas del patio de la mezquita de Córdoba”, Romula, 9 (2010), pp. 315-341. 


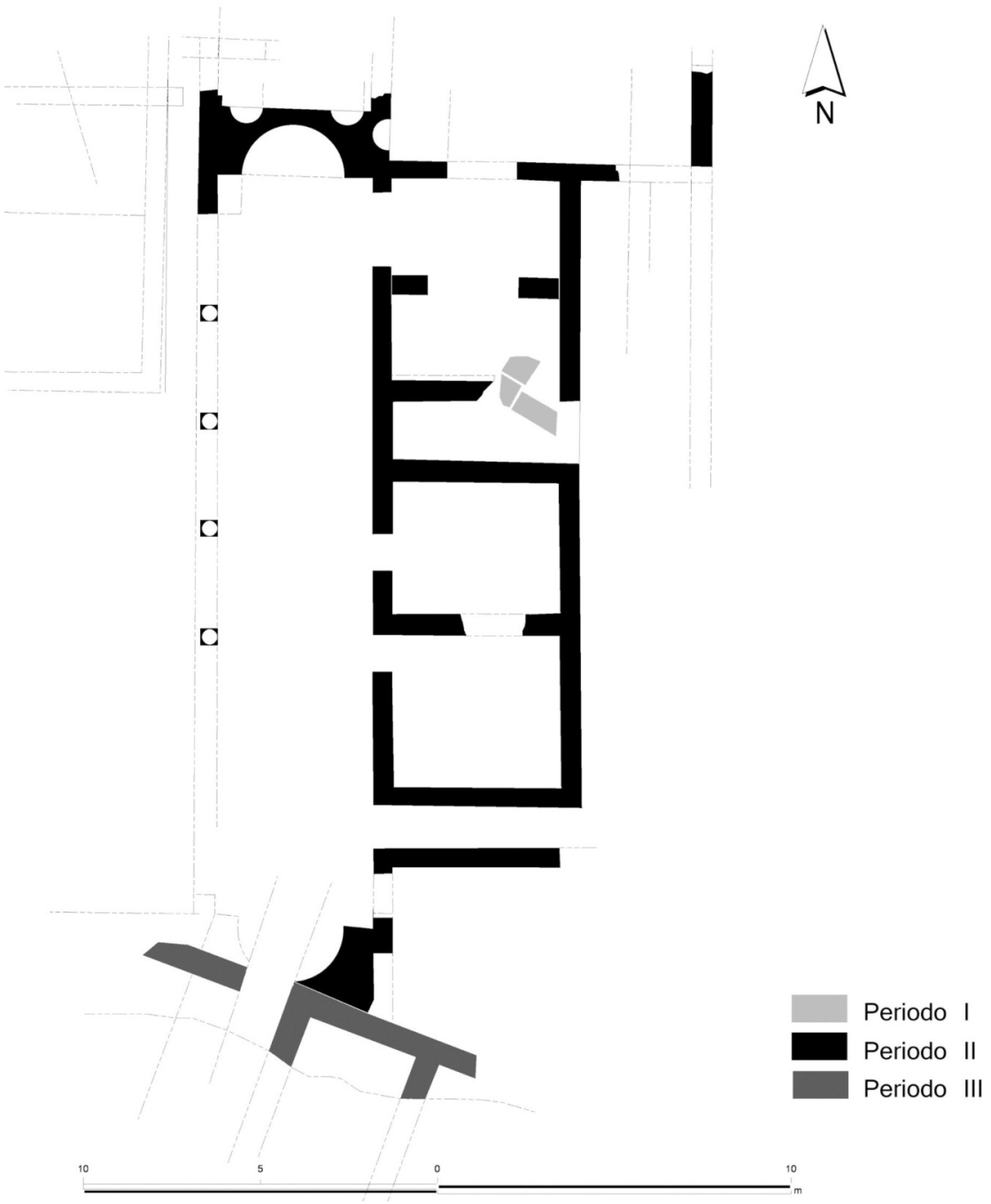

Figura 4. Secuencia de niveles constructivos en el patio, según José Manuel Bermúdez a partir de Félix Hernández y Antonio Fernández-Puertas, publicado en José Manuel

Bermúdez, "El atrium del complejo episcopal cordubensis. Una propuesta sobre la funcionalidad de las estructuras tardoantiguas del patio de la mezquita de Córdoba", Romula, 9 (2010), pp. 315-341. 
Isabel Sánchez ${ }^{43}$ defiende la existencia de una iglesia bajo la sala hipóstila de la mezquita a partir de la información de archivo. La clave de este reconocimiento pasa por la reorientación de cierta estructura absidada presente en los dibujos de Hernández. Dicho elemento era el único con posibilidades de ser algo parecido a la cabecera de un templo cristiano, pero tenía un problema: su anómala orientación hacia el suroeste. Dice que la orientación que le da Marfil es incorrecta y que habría que girarla $90^{\circ}$ (Figura 5). De esta forma se conseguiría una

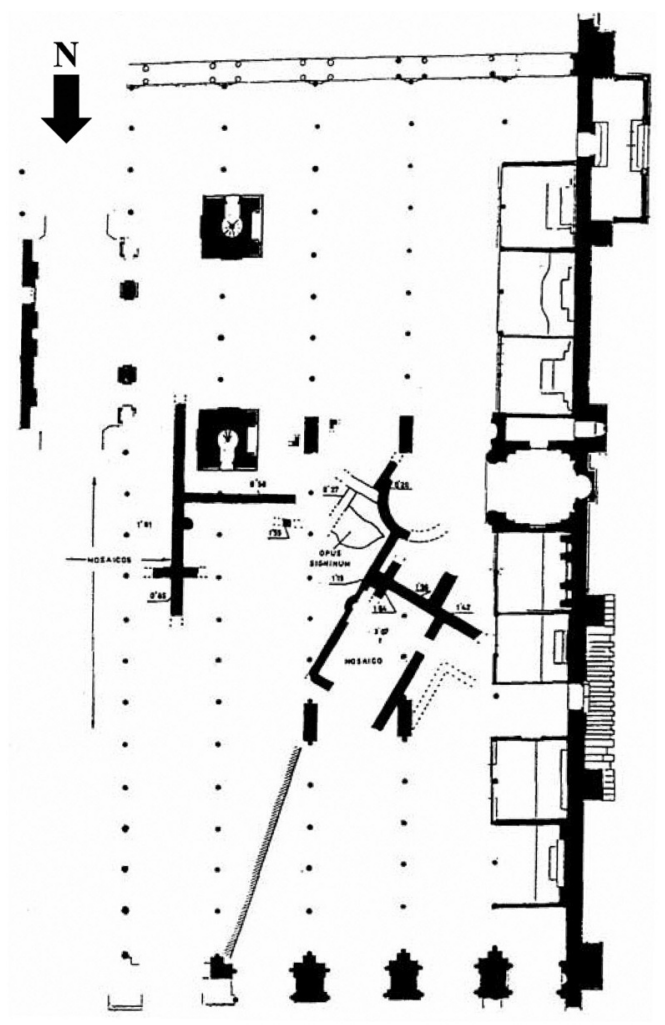

Figura 5. Localización de las estructuras encontradas por Félix Hernández en la sala de oración, según Pedro Marfil, "Córdoba de Teodosio a Abd al-Rahmán III", en L. Caballero y P. Mateos (eds.), Visigodos y omeyas. Un debate entre la tadoantigüedad tardía y la alta edad media, Anejos del Archivo Español de Arqueología, XXIII, Madrid, CSIC, 2000, pp. 117-141.

${ }^{43}$ Sánchez-Ramos, "Sobre el grupo episcopal de Corduba". 


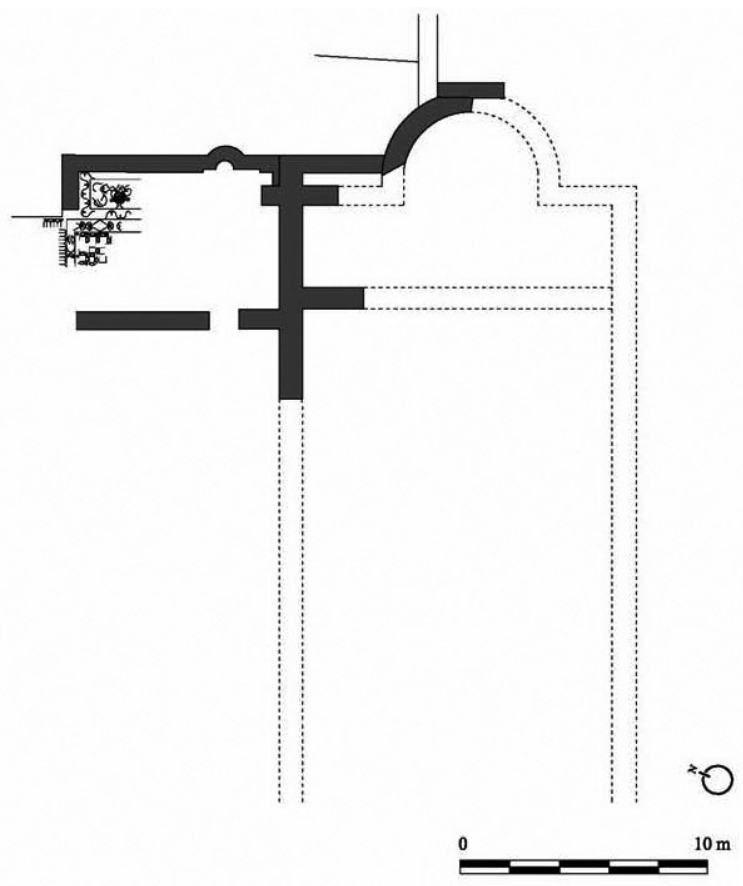

Figura 6. Propuesta de iglesia en el subsuelo de la sala de oración, según Isabel Sánchez-Ramos, "Sobre el grupo episcopal de Corduba", Pyrenae, 40, 1 (2009), pp. 121-147.

alineación cardinal de la iglesia cercana a lo canónico. La iglesia que presenta (Figura 6) es un templo de cabecera única y un aula sin divisiones longitudinales formando naves. En el lado norte hay una habitación rectangular aneja, sin comunicación con el cuerpo de fábrica anterior, con restos de mosaico en el pavimento y una hornacina en el muro oriental. Toma de Marfil la idea de un ámbito bautismal, fuera de la iglesia, delatado por un suelo hidráulico.

Mirando el plano los muros parecen estar en la misma cota, pero surgen muchas dudas. Bermúde $z^{44}$ aporta un dato que puede ser determinante: la evidente diferencia de cotas entre el arrasamiento del supuesto ábside (a 20-27 cm del suelo actual) y el arrasamiento de la habitación lateral (los muros a 119-198 cm y el suelo de mosaico a 307

${ }^{44}$ Bermúdez, "El atrium del complejo episcopal cordubensis", p. 324. 
cm; datos de Hernández) no hace factible que todo funcionara a un tiempo. El templo representado por Sánchez nos plantea además otros interrogantes. Es complicado entender cómo el muro recto que parece cortar o adosarse al ábside por su parte externa puede tener unidad constructiva con la fábrica a la que ataca. No es menos extraño el angosto espacio que se genera al norte de la embocadura del ábside, una especie de estrecha cámara incomunicada con el aula. Lo que parece un dudoso contrafuerte en el muro norte del templo invade la habitación lateral, algo ilógico si todo fue planificado de una vez.

La interpretación espaciofuncional tampoco resulta convincente. El supuesto sanctuarium sólo tiene a su favor su forma semicircular, absidada, profusamente documentada en la arquitectura romana definiendo espacios de diversa funcionalidad pública y privada. Añadamos a esto la ausencia de cualquier resto vinculado a la liturgia cristiana (altar, canceles) en el ábside cordobés. Para la habitación septentrional Sánchez baraja varias posibilidades funcionales (bautismal, funeraria, martirial, de sacrarium). Sin embargo, en el marco comparativo propuesto a partir de otras iglesias tardoantiguas mediterráneas, la autora pone de manifiesto las enormes dificultades para identificar en esta habitación cualquier uso de los antes apuntados ${ }^{45}$.

¿No estaremos actuando con más urgencia de la deseable en un intento por homologar nuestros restos tardoantiguos con los de otros lugares? ¿Podemos en verdad afirmar que contamos con modelos predictivos? J.M. Gurt e I. Sánchez ${ }^{46}$, en su planteamiento general sobre el asunto en la Península Ibérica, no alcanzan a definir una repetición invariable de respuestas, a lo sumo alguna tendencia. En el caso de Córdoba, incluso, hay datos que contradicen esas tendencias. Así ocurre con un hecho que se evita mencionar: no hay el más mínimo rastro de una necrópolis. Por no haber no hay ni una sola tumba. ¿Qué ocurre entonces con «la interconexión indisociable que parece existir entre espacios funerarios y espacios sagrados ${ }^{47} \gg$ ? Más adelante, en el mismo trabajo, se dice que «los grupos episcopales considerados urbanos [entre los que se incluye el de Córdoba], buscan y se establecen sobre

45 Sánchez-Ramos, "Sobre el grupo episcopal de Corduba", pp. 137-138.

${ }^{46}$ Gurt y Sánchez-Ramos, "La ciudad cristiana en el Mediterráneo occidental. La comprensión del mundo urbano tardío desde una perspectiva material".

${ }^{47}$ Gurt y Sánchez-Ramos, "Espacios funerarios y espacios sacros en la ciudad tardoantigua. La situación en Hispania", p. 15. 
espacios de necrópolis ${ }^{48} \gg$. El pretendido complejo de San Vicente incumple a las claras esta premisa. No había allí ninguna necrópolis, como parece ser normal en otros grupos episcopales, los seguros de Tarrasa $^{49}$ y del Tolmo de Minateda ${ }^{50}$ y los posibles de Barcelona ${ }^{51}$ y Valencia $^{52}$. Otra cuestión que el registro material no parece apoyar es que existió, vinculado a la catedral, un espacio bautismal. Pasando revista a los datos suministrados por otras ciudades, en efecto parece ser normal encontrar pilas bautismales en los entornos episcopales (El Tolmo, Tarrasa) pero, atención, se detecta cierta tendencia historiográfica que lleva a hablar de baptisterios en cuanto aparecen elementos materiales que tengan que ver con el agua ${ }^{53}$.

En el planteamiento sobre los complejos episcopales de las ciudades no se tiene en cuenta un factor de gran relevancia para muchas ciudades hispanas: que pasaron a formar parte de al-Andalus. Se habla de las transformaciones de la viejas urbes durante la Antigüedad Tardía como prefiguración de lo que serán las ciudades medievales sin plantearse la singularidad hispana derivada de la conquista islámica. No se está pasando, en muchas ocasiones, de la ciudad tardoantigua a la ciudad me-

${ }^{48}$ Gurt y Sánchez-Ramos, "Espacios funerarios y espacios sacros”, p. 19.

49 García, Moro y Tuset, La seu espiscopal d'Egara. Arqueologia d'un conjunt cristiá del segle IV al IX.

${ }_{50}$ Abad, Gutiérrez y Gamo, "La ciudad visigoda del Tolmo de Minateda (Hellín, Albacete) y la sede episcopal de Eio".

${ }^{51}$ Beltrán de Heredia (dir.), De Barcino a Barcinona (siglos I-VII). Los restos arqueológicos de la plaza del Rey de Barcelona.

${ }_{52}$ Ribera y Roselló (eds.), Los orígenes del cristianismo en Valencia y su entorno.

53 Aparte del caso cordobés hay otros lugares en los que la identificación de espacios bautismales parece forzada a tenor de las pruebas presentadas. Nos referimos a l'Almoina de Valencia y al Patio de las Banderas de los Reales Alcázares de Sevilla. En el primero, un desagüe que atraviesa un muro de una potente construcción y el prejuicio de que pegada a ella estaba la basílica catedralicia, sirven para proclamar el descubrimiento de un baptisterio (Ribera y Roselló, "Valentia en el siglo VII. De Suinthila a Teodomiro", p. 187). En Sevilla es la aparición de una pileta sucesivamente reformada (Bendala y Negueruela, "Baptisterio paleocristiano y visigodo en los Reales Alcázares de Sevilla") la que está haciendo arraigar la idea de que nos encontramos en un entorno de monumentalización cristiana en la que tendríamos una iglesia dotada, en su parte occidental, de un ámbito bautismal (Sánchez Ramos, "Arquitectura sacra de época tardía en Hispalis. Algunas reflexiones", pp. 258-259). Esta hipótesis, no obstante, encuentra opiniones en contra que abogan por explicaciones en clave doméstica y no litúrgica (Tarradellas, "Topografía urbana de Sevilla durante la Antigüedad Tardía”, p. 286). Parece claro que la historiografía hispana está falta de un estudio o estudios profundos y críticos sobre la realidad material de los baptisterios que ayuden y orienten de forma más rigurosa a la hora de identificarlos e interpretarlos. 
dieval cristiana. Esta última surge en no pocos casos de las medinas musulmanas. Debajo de muchas catedrales medievales hay mezquitas aljamas (Córdoba, Sevilla, Toledo, Granada, Tudela, Zaragoza) si bien, bajo éstas, todavía no se ha encontrado ninguna catedral preislámica. Lo mismo ocurre con las residencias palatinas musulmanas, que darán lugar a los alcázares cristianos. Esto nos lleva a tener que manejar otros modelos de implantación, los islámicos. En el contexto general de las ciudades musulmanas, sería muy extraño que en Córdoba, el nuevo poder, se hubiera lanzado desde el primer instante a depredar un complejo episcopal y una residencia palatina (el no menos mítico palacio de Rodrigo) ya que es algo que se escapa de la tendencia que se rastrea de un lado al otro del Mediterráneo. Los resultados de las excavaciones de la mezquita vienen a corroborarlo.

\section{Concluyendo}

Nuestra conclusión es que en las exploraciones arqueológicas emprendidas hasta ahora en la mezquita no han aparecido restos materiales que, sin discusión, puedan vincularse con iglesias preislámicas. No es ésta una propuesta original. Ya lo dijeron hace mucho los testigos directos de las excavaciones de los años 30, Hernández y Gómez-Moreno. En fechas más recientes otros investigadores de reconocida opinión como Luis Caballero piensan de igual forma:

A mi parecer, nada indica que estos restos pertenezcan a iglesias [...] Tampoco han aparecido restos de la primera mezquita que deberían interponerse entre los del supuesto conjunto de San Vicente y el edificio actual ${ }^{54}$.

¿Por qué seguimos hablando de la basílica de San Vicente? En nuestra opinión como consecuencia de una obstinación historiográfica heredera de un mito histórico. El mito era una fabulosa iglesia equiparable en monumentalidad y relevancia a la mezquita omeya. Un edifico imaginado e idealizado que las antiguas excavaciones demostraron que nunca existió. Las exploraciones de Hernández sacaron a la luz una realidad material que obligaba a buscar una nueva comprensión de los acontecimientos. Lo que parecía invitar a entrar en una etapa de refor-

${ }^{54}$ Caballero, “'Impacto' del Islam en la arquitectura cristiana”, p. 29. 
mulación fue sustituido por lo que llamamos una obstinación historiográfica. Tal vez animados por intentar subirnos a la nueva ola arqueológica de la Antigüedad Tardía hemos cambiado la idea de una fabulosa iglesia por la de un conjunto de edificios, más discretos monumentalmente, que conformaban el inevitable complejo episcopal que Córdoba debía tener. Naturalmente la presencia del poder eclesiástico tuvo que incidir materialmente en la ciudad pero ¿por qué ahí y no en otro sitio? La mítica basílica de San Vicente, desvanecida su imagen tras las excavaciones, pudo no obstante mantener una inercia historiográfica gracias a los trabajos de Ocaña y de los Santos. Actualmente se ha recogido el testigo historiográfico sin poner en cuestión ni criticar las bases conceptuales e interpretativas inerciales. Metodologías arqueológicas más rigurosas y la acumulación positiva de conocimiento sobre el periodo tardoantiguo gracias a un interés creciente por el tema y la capacidad para poder intervenir en importantes yacimientos urbanos, son los nuevos pilares interpretativos. Qué duda cabe que el marco de conocimiento actual es bastante más amplio que el de tiempos de Hernández y Gómez-Moreno. Pero precisamente porque tenemos más información llama la atención que nos empeñemos en decir que bajo la mezquita aljama hay un complejo episcopal cuando los datos arqueológicos y comparativos lo desdicen de forma bastante explícita.

Estas son las consecuencias de tipo historiográfico derivadas de nuestra conclusión. En lo tocante a la comprensión histórica, el hecho de que no haya ningún establecimiento religioso previo (cristiano o musulmán) supone lo siguiente:

Para empezar, que las diferentes tradiciones literarias que de una u otra forma apelaban a la existencia de edificios de culto (bien iglesias, bien mezquitas reconvertidas o de nueva planta) deberán ser valoradas de una manera distinta. Hablamos de construcciones de memoria que necesitan ser entendidas desde otros puntos de vista.

En segundo lugar hemos de poner en duda aquellas situaciones históricas derivadas de los efectos materiales transmitidos por los distintos relatos. Por ejemplo, si no existió la basílica de San Vicente en el contexto de la tradición de Ibn 'I deârī y al-Maqqarī, jamás se produjo la partición del templo ni, por supuesto, la destrucción de todas las iglesias de Córdoba y su posterior reparación décadas más tarde. Si nos vamos a las noticias que hablan de la fundación, desde los cimientos, de una mezquita tras la conquista, de nuevo las evidencias materiales 
nos dicen que los musulmanes no levantaron aquí una de las primeras mezquitas de al-Andalus. Al no haber ni iglesias ni mezquitas, todo lo que se ha dicho sobre cuestiones relativas a las formas y ritmos de la implantación musulmana en Córdoba así como su impacto sobre la sociedad mozárabe local en época temprana debería ser revisado.

El registro arqueológico revela que fue necesario derribar una serie de espacios arquitectónicos que estaban en pie y en uso para preparar el solar de la futura mezquita aljama. Por lo que sabemos hasta ahora, los edificios afectados no eran centros de culto cristiano o musulmán, siendo imposible además determinar si su titularidad, en el momento de la construcción de la aljama, era musulmana o cristiana. Habría que repensar con quién y en qué condiciones negoció el poder omeya, si es que lo hizo.

Cualquier esclarecimiento sobre la historia de la aljama cordobesa deberá pasar por la puesta en marcha de nuevos acercamientos arqueológicos en un edificio con una enorme potencialidad apenas explotada más allá de las parciales exploraciones del siglo pasado. Tenemos amplias zonas nunca excavadas y contamos, además, con el propio edificio en pie que puede ser analizado en sus alzados según los mismos criterios metodológicos. Que se acometan en el futuro este tipo de trabajos es algo imposible de predecir, al igual que sus resultados pero, mientras tanto, lo que sabemos actualmente es suficiente para poner en entredicho tradicionales discursos históricos ${ }^{55}$.

\section{Bibliografía}

Abad, Lorenzo, Gutiérrez, Sonia y Gamo, Blanca, "La ciudad visigoda del Tolmo de Minateda (Hellín, Albacete) y la sede episcopal de Eio", en Albert Ribera y Miquel Roselló (eds.), Los orígenes del cristianismo en Valencia y su entorno, Valencia, Ajuntament, 2000, pp. 101-112.

Arce-Martínez, Javier, "Emperadores, palacios y villae (a propósito de la villa romana de Cercadilla, Córdoba)", Antiquité Tardive, 5 (1997), pp. 293-302.

Arce-Sainz, Fernando, "Construcción de iglesias en la Córdoba emiral: testimonios literarios", en Actas del III Congreso de Historia de Andalucía, Córdoba,2001, Córdoba, Obra Social y Cultural Cajasur, 2003, pp. 293-303.

\footnotetext{
${ }^{55}$ Nosotros mismos, en algún trabajo anterior, hemos sido partícipes de ellos (Arce-
} Sainz, "Construcción de iglesias en la Córdoba emiral: testimonios literarios"). 
Beltrán de Heredia, Julia (dir.), De Barcino a Barcinona (siglos I-VII). Los restos arqueológicos de la plaza del Rey de Barcelona, Barcelona, MHCB-Ajuntament de Barcelona-Institut de Cultura Barcelona, 2001.

Bendala, Manuel y Negueruela, Iván, "Baptisterio paleocristiano y visigodo en los Reales Alcázares de Sevilla”, Noticiario Arqueológico Hispano, 10 (1980), pp. 337-339.

Bermúdez, José Manuel, "El atrium del complejo episcopal cordubensis. Una propuesta sobre la funcionalidad de las estructuras tardoantiguas del patio de la mezquita de Córdoba", Romula, 9 (2010), pp. 315-341.

Caballero, Luis, “'Impacto' del Islam en la arquitectura cristiana que se conservó o se reconstruyó en al-Andalus (o bajo domino musulmán)", en Alfonso Jiménez (ed.), De Hispalis a Isbiliya, Sevilla, Catedral de Sevilla, Aula Hernán Ruiz, 2009, pp. 15-58.

Calvo, Susana, "Las primeras mezquitas de al-Andalus a través de las fuentes árabes (92/711-170/785)", Al-Qanțara, 38 (2007), pp. 143-179.

Calvo, Susana, “Analogies entre les Grandes Mosquées de Damas et Cordoue: mythe et réalité", en Antoine Borrut y Paul M. Cobb (eds.), Umayyad Legacies. Medieval Memories from Syria to Spain, Leiden, Brill, 2010, pp. 281-311.

Calvo, Susana, "Les premières mosquées et la transformation des sanctuaires wisigothiques (92H/711-170H/785)", Mélanges de la Casa de Velázquez, 41-2 (2011), pp. 131-163.

Dupré, Xavier (ed.), Las capitales provinciales de Hispania, 1, Colonia Patricia Corduba, Córdoba, Universidad, 2004.

Fairchild Ruggles, D., "La estratigrafía del olvido: la gran mezquita de Córdoba y su legado refutado", Antípoda, 12 (2011), pp. 18-37.

Fernández-Puertas, Antonio, "Bosquejo sobre la labor científica de Don Félix Hernández Giménez", Cuadernos de la Alhambra, 10-11 (1974-75), pp. 1-9.

Fernández-Puertas, Antonio, Mezquita de Córdoba. Su estudio arqueológico en el siglo XX, Granada, Universidad, 2009.

Frochoso-Sánchez, Rafael, "Las monedas encontradas en la excavación de la Catedral de Córdoba", Arte, Arqueología e Historia, 16 (2009), pp. 195-204.

García, Gemma, Moro, Antonio y Tuset, Francesc, La seu espiscopal d'Egara. Arqueologia d'un conjunt cristiá del segle IV al IX, Tarragona, ICAC, 2009, Sèrie Documenta, 8.

Gómez-Moreno, Manuel, El arte árabe español hasta los almohades, Madrid, Editorial Plus-Ultra, 1951, Ars Hispaniae, III.

Gurt, Josep Maria y Sánchez-Ramos, Isabel, "Espacios funerarios y espacios sacros en la ciudad tardoantigua. La situación en Hispania", en Alfonso García (coord.), Espacios urbanos en el occidente mediterráneo (S. VI-VIII), Actas del I Congreso Internacional Toledo. Espacios en el occidente Mediterráneo (s. VI-VII), 2010, Toledo, Toletvm Visigodo, pp. 15-28. 
Gurt, Josep Maria y Sánchez-Ramos, Isabel, "La ciudad cristiana en el Mediterráneo occidental. La comprensión del mundo urbano tardío desde una perspectiva material", Mainake, 31 (2009), pp. 131-147.

Hidalgo, Rafael, El criptopórtico de Cercadilla, análisis arquitectónico y secuencia estratigráfica, Sevilla, Consejería de Cultura, 1996.

Hidalgo, Rafael y Marfil, Pedro, "El yacimiento arqueológico de Cercadilla: avance de resultados", Anales de Arqueología Cordobesa, 3 (1992), pp. 277-308.

Ibn 'Idārī, Bayan al-Mugrib. Histoire de l'Afrique et de l'Espagne, Edmond Fagnan (trad.), Argel, s.e., 1901-1904.

Ibn Hayyān, Crónica de los emires Alhakan I 'Abdarrahman entre los años 796847, Muqtabis II-1, Mạ̣mūd 'Alī Makki y Federico Corriente (trads.), Zaragoza, IEIOP, 2001.

Lafuente y Alcántara, Emilio (trad.), Ajbār Maŷmü a fi fath al-Andalus wa-dhikr umarā 'i-hā, Colección de tradiciones sobre la conquista de al-Andalus, Madrid, Real Academia de la Historia, 1867.

Lammens, Henri, Etudes sur le siècle des omayyades, Beirut, Imprimerie Catholique, 1930.

Al-Maqqarī, The History of the Mohammedan Dynasties in Spain extracted from the Nafhu-t-tīb min ghosni-l-andalusi-r-rattīb wa tárikh Lisánu-d-Dīn Ibni-l-Khattīb, Pascual de Gayangos (trad.), Londres, Oriental Translation Fund., 1840-1843.

Marfil, Pedro, "Córdoba de Teodosio a Abd al-Rahmán III", en Luis Caballero y Pedro Mateos (eds.), Visigodos y omeyas: un debate entre la Antigüedad tardía y la Alta Edad Media, Madrid, CSIC, 2001, pp. 117-141, Anejos del Archivo Español de Arqueología, XXIII.

Marfil, Pedro, "El complejo cristiano de Cercadilla (Córdoba)", Anales de Arqueología Cordobesa, 21-22 (2010-2011), pp. 241-251.

Marfil, Pedro, "La basílica de San Vicente en la catedral de Córdoba", Arqueología, Arte e Historia, 14 (2007), pp. 185-196.

Marfil, Pedro, "La iglesia paleocristiana de Santa Catalina en el convento de Santa Clara", Caetaria, 1 (1996), pp. 33-45.

Marfil, Pedro, "La sede episcopal de San Vicente en la santa iglesia Catedral de Córdoba", Al-Mulk, 6 (2006), pp. 35-58.

Molina, Luis (trad.), Dikr bilād al-Andalus, Madrid, Instituto Miguel Asín, 1983.

Nieto, Manuel, La catedral de Córdoba, Córdoba, Obra Social y Cultural Cajasur, 1998.

Ocaña, Manuel, "La basílica de San Vicente y la gran mezquita de Córdoba. Nuevo examen de los textos", Al-Andalus, 7, 2 (1942), pp. 347-366.

Ocaña, Manuel, "El mito de la Basílica de San Vicente de Córdoba", en Manuel Castillejo (ed.), La mezquita de Córdoba. Textos para su historia, Córdoba, Publicaciones del Monte de Piedad y Caja de Ahorros, 1986, pp. 129-134.

Ribera, Albert y Roselló, Miquel (eds.), Los orígenes del cristianismo en Valencia y su entorno, Valencia, Ajuntament, 2000. 
Ribera, Albert y Roselló, Miquel, "Valentia en el siglo VII. De Suinthila a Teodomiro", en Luis Caballero, Pedro Mateos y M. Ángeles Utrero, El siglo VII frente al siglo VII, Madrid, CSIC, 2009, pp. 185-203, Anejos de Archivo Español de Arqueología, LI.

Ripoll, Gisella y Darder, Marta, "Frena equorum. Guarniciones de frenos de caballos en la antigüedad tardía hispánica", Espacio, Tiempo y Forma, serie I, 7 (1994), pp. 277-356.

Sánchez-Ramos, Isabel, “Arquitectura sacra de época tardía en Hispalis. Algunas reflexiones”, Archivo Español de Arqueología, 82 (2009), pp. 255-274.

Sánchez-Ramos, Isabel, "Sobre el grupo episcopal de Corduba", Pyrenae, 40, 1 (2009), pp. 121-147.

Sánchez-Velasco, Jerónimo, Elementos arquitectónicos de época visigoda en el Museo Arqueológico de Córdoba. Arquitectura y urbanismo en la Córdoba visigoda, Córdoba, Museo Arqueológico y Etnológico de Córdoba, 2006.

Santos-Gener, Samuel de los, "Las artes en Córdoba durante la dominación de los pueblos germánicos”, Boletín de la Real Academia de Córdoba, 78 (1958), pp. 147-192.

Tarradellas, M. ${ }^{\text {a }}$ Cristina, "Topografía urbana de Sevilla durante la Antigüedad Tardía”, en Josep Maria Gurt y Núria Tena, V Reunió d'Arqueologia Paleocristiana Hispánica, Cartagena 1998, Barcelona, Institut d'Estudis Catalans, 2000, pp. 279-290.

Utrero, M. a Angeles, "Las iglesias cruciformes del siglo VII en la Península Ibérica. Novedades y problemas cronológicos y morfológicos de un tipo arquitectónico", en Luis Caballero, Pedro Mateos y M. Angeles Utrero, El siglo VII frente al siglo VII, Madrid, CSIC, 2009, pp. 133-154, Anejos de Archivo Español de Arqueología, LI.

Vaquerizo, Desiderio y Murillo, Juan Francisco (eds.), El anfiteatro romano de Córdoba y su entorno urbano. Análisis arqueológico (ss. I-XIII), Córdoba, Universidad, 2010, Monografías de Arqueología Cordobesa, 19.

Vicent, Ana María, "Perfil científico y humano de D. Félix Hernández”, Corduba, 3, I-3 (1976), pp. 165-198.

Recibido: 09/02/2012

Aceptado: 09/09/2013 